\title{
KREASI KOMIK PUTAR BERTEMA PROBOLINGGOAN DALAM MENGGAMBAR KOMIK DI SMPN 2 GENDING KABUPATEN PROBOLINGGO
}

\author{
Kasim Suharyoso \\ Sekolah Menengah Pertama Negeri 2 Gending \\ Jl. Sumberkerang Gending, Kabupaten Probolinggo, 67272 \\ Jawa Timur. Indonesia \\ Email: kasim.suharyoso@gmail.com
}

\begin{abstract}
Abstrak
Penelitian ini berawal dari kondisi kemampuan siswa dalam menggambar komik belum maksimal, teknik menggambar masih asal-asalan, kegiatan menggambar komik masih dilakukan dengan cara mencontoh gambar yang sudah ada, bahkan yang mereka contoh adalah komik luar yang tidak mencerminkan budaya Indonesia. Kondisi ini memerlukan strategi yang dapat mengembangkan kreativitas, berfikir kritis, kolaboratif, dan komunikatif peserta didik. Strategi yang dipergunakan adalah Kreasi Komik Putar bertema Probolinggoan. Aktivitas pembelajaran berupa kegiatan mengkreasi gambarkomik pada media kerdus/ kotak kemasan bekas yang dibagian tengahnya diberi poros kayu sehingga dapat diputar. Metode penelitian pengembangan dengan merujuk pada konsep EDDIE ini diterapkan pada kelas VIII D sebagai subjek penelitian, data diperoleh dari hasil observasi, penilaian karya, dan kuesioner. Dari penerapan strategi ini diperoleh peningkatan kemampuan menyusun alur cerita $60.71 \%$, teknik menggambar 64, $29 \%$ dan menentukan karakter tokoh sebesar $25 \%$.
\end{abstract}

Kata Kunci: kreasi, komik putar, probolinggoan.

\begin{abstract}
This research began from the condition of students' competence in drawing comic which have not maximally achieved, their drawing technics are still relatively not good, the activities of drawing the comics are still done by imitating the available images, even what they have imitated a re foreign comics that do not reflect our Indonesian culture. This conditions need certain strategies that can develop the students' creativities, critical thinking, collaboratives, and the studentcommunications. The strategies that are used are the rolling camics with a Probolinggo circumstance theme, the learning activietis are the activietis of creating comic drawing towards cardboardmedium or used sachet boxes which are in the middle of them given wood pivot, so that theycan be rolled. The developing reseach methodss are by referring towards EDDIE concepts, which are implemented to the students of VIII D grade as the data are subjets, the data are obtained from observation results, work evaluation, and questionaires. From the implemention of this strategies can be obtained the increasing the students' competences in arranging the storyplot 60,71\%, drawing technics 64,29\%, and the maincharacters as much $25 \%$.
\end{abstract}

Keywords: creation, rolling comics, probolinggoan.

\section{PENDAHULUAN}

Pendidikan merupakan usaha sadar, terencana, dan sistematis sebagai upaya dalam membimbing dan menyiapkan peserta didik mencapai derajat kemanusiaan, memiliki kecerdasan, keluhuran budi, dan kecakapan yang dibutuhkan dalam hidupnya. Pendidikan dalam hal ini berfungsi membantu peserta didik mengembangkan potensinya untuk menghadapi masa depan ( Samami, 2011: 12). Sehingga peran Peran guru menciptakan situasi, memberikan informasi dan membimbing agar anak dapat mengkonstruksi pemahaman/ ketrampilan tertentu dengan cepat dan benar (Samami, 2011: 13).

Sinergitas antara ilmu pengetahuan dan teknologi bersama industri di abad -21 telah melahirkan babak baru yang disebut Revolusi Industri 4.0. Menurut Rakhmah (https:m.kumparan.com) di era ini terjadi perubahan drastis tentang pola produksi dengan mengkolaborasikan dimensi manusia, teknologi, dan big data. Sifat kompetitif dan dinamis dengan perubahan yang sangat cepat sehingga soft skills dan 


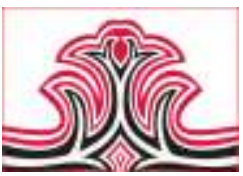

transversal skills menjadi s ang at penting untuk dimiliki oleh manusia.

Kondisi ini perlu disikapi secara arif dan bijaksana. Program pendidikan harus mampu mengimbangi arus perkembangan dan perubahan. Mindset berfikir kritis, kreatif, kolaboratif dan komunikatif sedini mungkin ditanamkan secara kuat dalam diri peserta didik. Pencapaian tujuan pendidikan sebagaimana dalam Undang-undang Sisdiknas harus menjadi perioritas utama.

Pendidikan Seni Budaya adalah bagian integral dari muatan kurikulum Pendidikan Nasional. Pembelajaran SeniBudaya bertujuan mengembangkan kepekaanrasa estetik dan artistik, sikap kritis, apresiatif, dan kreatif pada diri setiap peserta didik secara menyelunuh (Purnomo, 2016: 2). Salah satu materi pembelajaran SeniBudaya utamanya Seni Rupa adalah menggambar komik bagikelas VIII. Materiini bertujuan agar siswa memiliki pemahaman tentang konsep, teknik, dan prosedur menggambar komik.

Dalam pelaks anaan pembelajaran menggambar komik terdapat beberapa kendala yaitu: 1) siswa belum maksimal dalam berkarya komik. Hal ini dapat dilihat dari cara dan teknik menggambar masih asal-asalan;2) kegiatan menggambar komik masih dilakukan dengan cara mencontoh gambar yang sudah ada, sehingga belummuncul kreatifitas peserta didik.

Kenyataan ini kurang mendukung pencapaian tujuan pembelajaran. Kondisi ini perlu adanya perubahan dan peningkatan sehinggadiperoleh aktivitas pembelajaran yang lebih baik dan mampu membelajarkan siswa secara optimal. Proses peningkatan dapat tercapaibila pengalaman belajar sis wa dilaks anakan dalamsuasana yang menjamin adanya pengembangan kreativitas, inovatif, dan berfikir kritis. Untuk meng atasi kondisi di atas maka diterapkanlah Strategi Kreasi Komik Putar bertema Probolinggoan. Penerapan strategi ini bertujuan untuk meningkatkan kemampuan peserta didik dalammenggambarkomik.

Selain itu strategi ini diharapkan dapat memberikan manfaat baik secara teoritis sebagai pengembangan keilmuan seni maupun secara praktis menjadi pengalaman belajar yang mampu menarik minat sis wa, menggugah kreativitas, inovatif, kolaboratif, berfikir kritis dan mampu melestarikan budaya lokal pada pesertadidik. Dan akhirny a pembelajaran Seni Budaya di sekolah akan berjalan sesuai harapan dan tuntutan perubahan yang sang at cepat.
Gorga : Jurnal Seni Rupa Volume 09 Nomor 02 Juli-Desember 2019 p-ISSN: 2301-5942 | e-ISSN: 2580-2380

\section{KAJIAN TEORI}

\section{Teori Strategi Pembelajaran Seni}

Strategi adalah pola umum perbuatan guru dan siswa dalam proses pembelajaran yang dibangun atas dasar pemikiran cerdas untuk mengoptimalis asi hasil belajar (Soehardjo, 2011:9). Strategi dibangun melalui kerjasama yang harmonis antar elemen dalam pembelajaran. Setiap proses pembelajaran, memerlukan strategi yang tepat dan terencana. Ketepataan dalam memilih strategi akan berdampak pada hasil pembelajaran yang ingin dicapai. Sehingga dalam menyusun perencanaan kegiatan pembelajaran seorang guru dituntut menguasai strategipembelajaran dengan baik. Menurut Sani (2019:155) pemilihan strategi pembelajaran tidak terlepas dari kurikulum dan karakteristik peserta didik yang didalamnya termasuk pengalaman awal, pengetahuan peserta didik, minat, gay a belajar, dan perkembangan peserta didik.

Dari kedua konsep di atas dapat disimpulkan bahwa, dalam melaksanakan pembelajaran di kelas seorang guru harus memiliki dan mampu menciptakan strategi pembelajaran yang tepat. Kondisi ini dapat diperoleh melalui adanya kesesuaian antara materi pembelajaran sebagai konten dari kurikulum, siswa sebagai subjek didik, dan lingkungan sebagai medan sosial dimana sis wa berinteraksi secara luas. Sehingga guru dalam menyusun strategi yang akan dipergunakan dalam pembelajarannya tidak hanya melihat dari satu sisi saja, tetapi secara menyeluruh (holistic). Karena sinergitas yang terjalin dari semua unsur akan mampu mencapai tujuan pembelajaran secara optimal. Pemilihan strategi yang mampu membelajarkan siswa secara efektif, efisien, dan menyenangkan akan menciptakan susasana belajar bermakna, yang dapat membuat siswa termotivasi untuk terus beraktivitas dengan baik

Menurut Soehardjo (2011) dalam penyelenggaraan pendidikan seni secara formal terdapat dua konsep y aitu penularan senidan pemfungsian seni. Penularan seni dilakukan oleh guru dalam pembelajaran seni di lingkungan sekolah menengah kejuruan. Tugas guru adalah menularkan kemampuan dan ketrampilan berkesenian kepada peserta didik. Tujuan pembelajaran seni adalah transformasi kealiaan seni kepada peserta didik. Konsep ini berorientasi pada terkuasainya hasil belajar yang telah direncanakan (instructional effect) dan kurang mengusahakan pada hasilikutan (nuturant effect).

Konsep kedua adalah pemfungsian seni. Konsep ini diperankan oleh guru yang membelajarkan siswanya di lingkungan sekolah menengah umum, yaitu 
memfungsididikkan seni. Peran guru adalah memfungsikan seni untuk menumbuh-kembangkan potensi peserta didik melalui pembelajaran seni yang diampunya. Dampak dari pemfungsian seni selain untuk mencapai tujuan atau hasil belajar sebagaimana yang telah ditetapkan dalamperencanaan pembelajaran (instructional effect ) juga mengoptimalkan hasil ikutan (nuturant effect) selama proses pembelajaran.

Bertolak dari teori di atas maka, strategi yang di terapkan dalam pembelajaran iniadalah pemfungsian seni y ang berorientasi pada hasil belajar (instructional effect) dan hasil ikutan (nuturant effec). Keduanya menjadi prioritas untuk dicapai dalam proses pembelajaran.

Artinya bahwa pembelajaran seni di sekolah umum dalam hal ini SMP bukan bertujuan menciptakan siswa menjadi seorang seniman atau siswa harus mampu membuat karya seni berdas ar kreteria tertentu. Akan tetapi pendidikan seni dimaknai sebagai fungsididikkan sis wa. Artinya, sis wabelajar melalui s eni, siswa belajar dengan seni, dan siswa belajar tentang seni. Sehingga melalui pembelajaran seni di sekolah antar siswa yang memiliki bakat seni dan yang tidak berbakat dapat terlayani untuk belajar tentang seni. Pengalaman pembelajaran seni yang diperolehny a s ebagai cara atau media bagaimana siswa belajar. Melalui kegiatan seni yang memiliki sifat indah, kreatif, inovatif, mandiri, kerja keras diharapkan mampu mendidik sis wa ke arah yang lebih baik.

\section{Menggambar Komik}

Kata komik berasal dari bahasa Inggris comics yang berarti perwujudan sastra gambar, comique (Prancis) yang berarti lucu atau menggelikan, komikos dari bahasa Yunani (Susanto, 2011:226). Komik diartikan sebagai narasi yang diceritakan melalui sejumlah gambar (Ratna, 2013:230). Artinya komik merupakan gambar yang di susun baik secara horisontal maupun berupa kotak atau strip untuk menceritakan sebuah narasi. Komik dalam hal ini merupakan serangkaian gambar yang bercerita, mirip sebuah naskah, tetapi dalam bentuk komposisi gambar dan dialog.

Menurut Susanto (2011:25) bentuk-bentuk komik yang ada di Indonesia seperti komik strip (comics strips) dan buku komik (comics book). Komik strip berbentuk komik bersambung layaknya cergam dalam sebuah majalah. Komik strip dibuat deng an rangkaian cerita yang pendek/ singkat sehingga tidak memerlukan gambar/ halaman dengan jumlah banyak atau benpa rangkaian cerita yang kompleks, tetapi dimuat/ ditampilkan secara bersambung. Buku komik (comics
Gorga : Jurnal Seni Rupa

Volume 09 Nomor 02 Juli-Desember 2019

p-ISSN: 2301-5942 | e-ISSN: 2580-2380

book) merupakan bentuk komik dengan mengetengahkan tema komplek sehingga memerlukan gambar dan halaman yang banyak dalam perwujudannya.

Ini menandakan bahwa komik memiliki bentuk yang tidak konstan, tetapi dapat saja berbentuk yang lain. Tetapi tetap tidak meninggalkan ciriutama dari komik yang memiliki komposisi bersifat rangkaian gambar, tulis an (cerita dan dialog).

\section{1). Langk ah-Langkah Menggambar Komik}

Hariadi (2017: 136 ) menjabarkan bahwa ada9 langkah dalam mengg ambar komik yaitu: 1) membuat plot yaitu struktur/ rangkaian cerita dari awal hingga penyelesaian; 2) mendefinisikan Karakter, yaitu menentukan karakter dari tokoh komik disesuaikan dengan peran yang dibawakan dalam cerita; 3) membuat draf dengan pensil yaitu mulai menggambar berupa sketsa menggunakan pensil; 4) membentuk outline gambar dengan menggunakan media pensil atau drawing pen; 5) menghapus draf pensil agar gambar terlihat rapi; 6) membuat detail gambar berupa wama rambut, pakaian, gelap terang, pose tokoh, dan detail yang lain; 7) melakukan koreksi; 8) menambahkan screentone atau bagian gelap terang, atau tekstur gambar; 9) menambahkan dialog.

Tahapan menggambar komik di atas pada dasamya memuat kegiatan yang dapat diglobalkan menjadi tahapan persiapan, proses kreatif, dan finishing. Dalam persiapan termasuk didalamnya menyiapakan semua media berupa peralatan meng gambar dan naskah cerita. Tahap proses kreatif meliputi kegiatan sketsa (membuat goresan secara sederhana / global), mewama dan memberikan unsur secara detail. Sedang tahapa finishing berupa proses perbaikan dari semua kesalahan agar gambar tampak sempurna, begitu juga dilakukan penulisan dialog dan cerita.

\section{Kreasi Komik Probolinggoan}

Kreasi Komik Putar artinya aktivitas pembelajaran berupa kegiatan mengkreasi g ambar komik pada media kerdus/ kotak kemas an bekas dan dibagian tengahnya diberi poros kayu sehingga dapat diputar. Proboling goan artinya tema meng gambar komik adalah hal yang berkaitan dengan kearifan lokal masyarakat Probolinggo. Rancang bangun Kreasi Komik Putar bertema Probolinggoan berbentuk tiga dimensi menyerupai bangunan candi seperti dalam Gambar 1 berikut: 

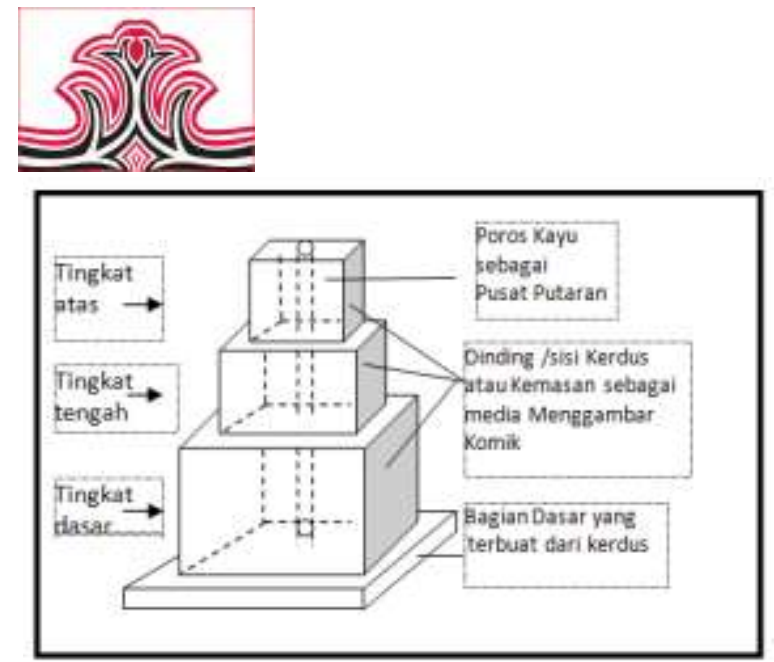

Gambar 1. Rancangan Bangun Komik Putar (Sumber: Kasim Suharyoso, 2020)

Proses awal sebagai berikut:

Kerdus/ kotak kemasan bekas yang telah disiapkan dibuka penyambungnya dengan tidak merusak permukaannya. Jika lebar sisi kerdus/kotak kemasan sama maka dapat langsung dijadikan media menggambar komik, tetapi jika tidak, maka sisi yang tidak diinginkan dipotong dan diganti kerdus/ kotak kemas an lain sesuai ukuran sebagaipengganti sisi yang tidak sama yang kemudian disambung menggunakan lem kertas sehingga ukuran sisi kerdus menjadi sama. Gambar 2 berikut merupakan contoh kerdus yang telah digambar.

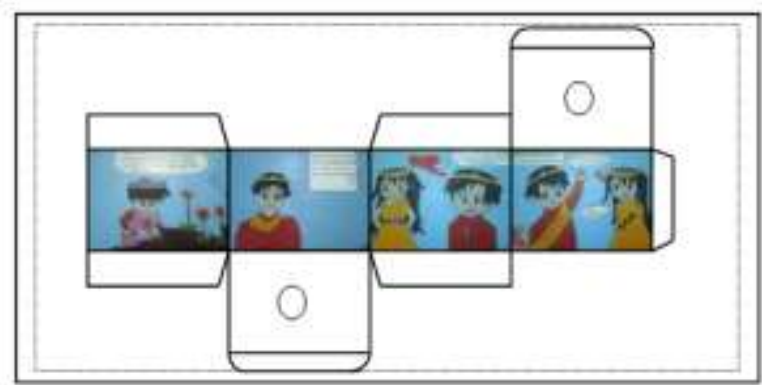

Gambar 2. Kardus/ Kotak Kemasan Setelah Proses Gambar (Sumber: Kasim Suharyoso, 2020)

Fungsi dari penerapan Pengembangan Strategi Kreasi Komik Putar bertema Probolinggoan ini yaitu: 1) untuk memotivasi, memiliki tantangan dan terpacu untuk melakukan proses menggambar komik dengan sungguh-sungguh; 2) membelajarkan siswa akan kreativitas dengan memanfaatkan kerdus/kotak bekas menjadi bentuk baru, dari sampah menjadi sesuatu yang bernilai; 3) memberikan pengalaman berinovasi.

\section{METODE PENELITIAN}

Penelitian ini menggunakan metode pengembangan desain sistem pembelajaran model ADDIE. Pribadi (2009:125) menjelaskan bahwa, sesuai dengan namanya, model ADDIE terdiri dari lima fase yaitu
(A)nalysis,
(D)esain,
(D)evelopment,

Gorga : Jurnal Seni Rupa

Volume 09 Nomor 02 Juli-Desember 2019

p-ISSN: 2301-5942 | e-ISSN: 2580-2380

(I)mplementation, (E)valuation. Kelima fase tersebut dapat dijelaskan sebagai berikut:

Analysis. Tahap Analysis terdiri dari dua tahap yaitu analisis kinerja (performance analysis) dan analisis kebutuhan (needAnalysis). Analisis kinerja (performance analysis) menunjukkan bahwa sebagian bes arsis wabelum mampu mengg ambar komik dengan baik (proses menggambar masih as al jadi, belum ada penggunaan warna), kegiatan menggambar komik selalu dilakukan dengan cara mencontoh gambar komik yang sudah ada. Sedangkan dari analisis kebutuhan (need Analysis) diperoleh gambaran perlunya peningkatan kemampuan teknik menggambar (kerapian, kebersihan, pewarnaan), menyusun alur cerita maupun karakter tokoh dan mempelajari cerita lokal sebag ai tema pembuatan komik.

Desain. Desain strategi pembelajaran menggunakan Strategi Kreasi Komik Putar bertema Probolinggoan yang meliputi kegiatan: identifikasi kearifan lokal, menentukan tema, analisis cerita/ naskah, desain, proses kreasi, dan komunikasi.

Development. Pengembangkan bahan ajar berupa pemenuhan sumber cerita, naskah/ cerita terkait Probolinggo melalui browsing internet, penelusuran literatur diperpustakaan, wawancara tokoh, dan sumber-sumber lain.

Implementation. Melaksanakan programpembelajaran dengan menerapkan desain atau spesifikasi pembelajaran. Kegiatan ini dilakukan dengan memberikan pengalaman menggambar komik menggunakan media kerdus/ kotak kemas an bekas.

Evaluation. Evaluasi dilakukan melalui evaluasi program pembelajaran dan evaluasi evaluasi hasil belajar. Evaluasi program pembelajaran dilakukan untuk mengetahui efektifitas Strategi Kreasi Komik Putar bertema Probolinggoan dalam membelajarkan siswa. Evaluasi program ini berdasar instrumen observasi keaktifan siswa, peningkatan hasil karya sis wa dan kuesioner yang disebar setelah pembelajaran selesai. Sedang evaluasi hasil belajar dilakukan dengan cara menilai hasil karya sis wa. Penelitian ini dilakukan di SMPN 2 Gending Kabupaten Probolinggo. Subjek penelitian adalah siswa kelas VIIID yang berjumlah 28 siswa.

Teknik pengumpulan data berupa observasi, kuesioner, penilaian karya siswa, dan validasi ahli. Analisis data dilakukan melalui proses membandingkan antara hasil pembelajaran sebelum dan sesudah pelaksanaan 
pengembangan. Observasi beris ikan tingkat keaktifan siswa selama mengikuti pembelajaran yang dibuat berupa lembar observasi. Kegiatan observasi dilakukan dengan cara centang pada pilihan sesuai kondisi siswa. Penilaian karya siswa terdiri dari aspek teknik menggambar, menentukan plot atau alur, membuat karakter tokoh. Rentang penilain dibuat sebagai berikut: nilai 50-69 kategori kurang, nilai 70-79 kategori cukup, nilai 80-89 kategori baik, dan 90 - 100 kategori baik sekali.

Kuesioner dilaksanakan melalui penyebaran angket yang berisikan daftar pernyataan tertutup pada siswa tentang pembelajaran. Artinya siswa tinggal memberikan tanda centang pada pilihan dalam daftar pertanyaan.

Validasi ahli dilakukan melalui teman sejawat dalam forum MGMP Mata Pelajaran Seni Budaya. Pemilihan validasi ahli berdasar latar belakang pendidikan yang telah ditempuhnya yaitu pendidikan seni.

\section{HASIL DAN PEMBAHASAN}

\section{Hasil}

Kegiatan pembelajaran melalui strategi kreasi komik putar bertema probolinggoan dilaksanakan sesuai langkah-langkah dalam desain pembelajaran yang meliputi: Tahap Identifikasi. Yaitu tahap mengumpulkan berbagai narasi/ cerita, naskah tentang tentang kearifan lokal mas yarakat Probolinggo. Narasi cerita, naskah yang dimaksud terkait dengan sosialbudaya, pariwisata, sejarah, dongeng, maupun folklor yang berkembang di masy arakat Probolinggo.

Menentukan tema. Setelah terkumpul narasi/cerita, naskah kemudian dipilih salah satu untuk dijadikan tema dalam menggambar komik.

Tahap Analisis. Pada tahap ini dilakukan proses analis is narasi/ cerita, naskah untuk mempelajari sekaligus menentukan tokoh, alur cerita/plot, dan setting cerita.

Tahap Desain. Tahap ke empat adalah desain/mendesain. Dari hasil analisis kemudian dirancang/ didesain bentuk gambar komik/visualnya. Tahap Kreasi. Tahap kreasi merupakan proses mengkreasi gambar pada media kerdus/kotak kemasan bekas. Aktivitas kreasi berupa kegiatan memindah gambar, mewarna gambar, dan finis hing gambar.

Tahap Komunikasi. Proses ini dilakukan melalui pres entasi di depan kelas. Proses ini bertujuan melatih keberanian siswa untuk bicara di depan kelas, bertanggung jawab terhadap hasil kreasi, sebagai
Gorga : Jurnal Seni Rupa

Volume 09 Nomor 02 Juli-Desember 2019

p-ISSN: 2301-5942 | e-ISSN: 2580-2380

pembelajaran bagis is wa lain, juga untuk mendapatkan umpan balik dari sis wa lain.

\section{1).Hasil Kegiatan Identifikasi Kearifan Lokal Masyarakat Probolinggo}

Berdasarkan dari kegiatan identifikasi kearifan lokal yang dilakukan oleh peserta didik diperoleh beberapa naskah/cerita kearifan lokal Probolinggo sebagai berikut: 1) Perjalanan Raja Majapahit ke Candi Jabung; 2) Dewi Rengganis; 3) Asal-u sulDes a Sumberkerang; 4) Joko Seger dan Rara Anteng); 5) budaya Gerabah Alaskandang; 6) As al-u sul Kota Probolinggo; 7) Asalusul Tari Glipang, 8) Air Terjun Madakaripura;8) Pesta Panen Bawang

Dari hasil identifikasitersebut kemudian siswa memilih salah satu naskah untuk di angkat menjadi tema dalam menggambar komik. Proses dilanjutkan pada tahap kreasi. Tahap kreasi merupakan proses mengkreasi gambar pada media kerdus/ kotak kemasan bekas. Aktivitas kreasi berupa kegiatan memindah gambar, mewarna gambar, dan finishing gambar. Dari pelaks anaan strategi ini diperoleh karya sis wa benupa komik putar sebagaimana Gambar 3 berikut:

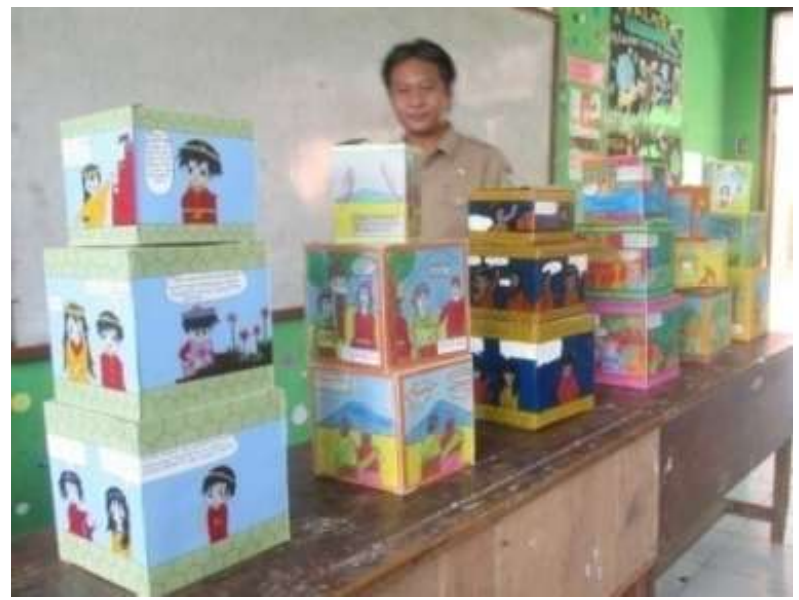

Gambar 3. Karya Komik Putar (Sumber: Kasim Suharyoso, 2020)

\section{2).Peningkatan Kemampuan Membuat Alur Cerital Plot}

Peningkatan kemampuan membuat alur cerita dijelas kan dalam Tabel 1 berikut:

Tabel 1. Peningkatan Kemampuan Membuat Alur Cerita/ Plot

\begin{tabular}{|c|c|c|}
\hline Kondisi & Jumlah Siswa & $(\%)$ Persentase \\
\hline Meningkat & 18 & $64,28 \%$ \\
\hline Tetap & 9 & $32,14 \%$ \\
\hline Menurun & 1 & $3,57 \%$ \\
\hline
\end{tabular}


Berdasarkan tabel di atas dapat dijelaskan bahwa peningkatan siswa dalam membuat alur cerita/ plot yaitu, ada 18 sis wa atau 64,28\% dapat meningkatkan kemampuannya, 9 siswa atau 32,14\% tetap, dan 1 siswa atau 3,57\% mengalami penurunan. Dari data di atas dapat disimpulkan bahwa peningkatan membuat alur cerita adalah $60.71 \%$.

\section{3). Peningkatan Kemampuan Teknik Menggambar} Peningkatan kemampuan teknik menggambar dijelaskan oleh Tabel 2 berikut:

Tabel 2. Peningkatan Kemampuan Teknik Menggambar

\begin{tabular}{|c|c|c|}
\hline Kondisi & Jumlah Siswa & $(\%)$ Persentase \\
\hline Meningkat & 23 & $82,14 \%$ \\
\hline Tetap & 5 & 17,85 \\
\hline Menurun & 0 & $0 \%$ \\
\hline
\end{tabular}

Tabel di atas menunjukkan bahwa siswa yang dapat meningkatkan kemampuan dalam teknik menggambar adalah sebagai 23 siswa atau 82, $14 \%$ dan yaitu 5 siswa atau $17,85 \%$ tetap tidak meningkat maupun menurun. Ini berarti terjadi peningkatan y ang s angat tinggi.

\section{4). Peningkatan Kemampuan Membuat Karakter}

Peningkatan kemampuan membuat karakter dijelaskan oleh Tabel 3 berikut:

Tabel 3. Peningkatan Kemampuan Membuat Karakter

\begin{tabular}{|c|c|c|}
\hline Kondisi & Jumlah Siswa & (\%) Persentase \\
\hline Meningkat & 13 & $46,42 \%$ \\
\hline Tetap & 9 & $32,14 \%$ \\
\hline Menurun & 6 & $21,42 \%$ \\
\hline
\end{tabular}

Tabel di atas menunjukkan bahwa kemampuan siswa dalam membuat karakter adalah 13 sis wa atau 46, 42 mengalami peningkatan, 9 sis wa atau 32,14 tetap tidak meningkat ataupun menurun, dan 6 siswa atau 21,42 mengalami penurunan. Dari data tersebut dapat disimpulkan bahwa peningkatan kemampuan siswa dalam membuat karakter tokoh adalah $25 \%$.

\section{5).Peningkatan Rata-Rata Nilai}

Tabel 4. Peningkatan Rata-Rata Nilai

\begin{tabular}{|c|c|c|}
\hline Kondisi & Jumlah Siswa & $(\%)$ Persentase \\
\hline Meningkat & 22 & $78,57 \%$ \\
\hline Tetap & 5 & 17,85 \\
\hline Menurun & 1 & $3,57 \%$ \\
\hline
\end{tabular}

Tabel di atas menjelaskan bahwa, perolehan rata-rata nilai sis wa dalam mengg ambar komik adalah sebanyak 22 siswa atau 78,57\% mengalami peningkatan, dan 5 orang siswa atau $17,85 \%$ beradapada posisi tetap, dan
Gorga : Jurnal Seni Rupa

Volume 09 Nomor 02 Juli-Desember 2019 p-ISSN: 2301-5942 | e-ISSN: 2580-2380

sisanya yaitu 1 siswa atau 3, $57 \%$ mengalami penurunan. Dari data tersebut diperoleh kesimpulan bahwa $75 \%$ sis wa meningkat rata-rata nilainya.

Has il kuesioner siswa dapat ditunjukkan dalam Tabel 5 berikut:

Tabel 5. Data Hasil Kuesione

\begin{tabular}{|c|l|c|c|c|}
\hline \multirow{2}{*}{ No } & \multicolumn{1}{|c|}{ Uraian Kompetensi } & \multicolumn{3}{|c|}{ Pencapaian } \\
\cline { 3 - 5 } & Penyediaan Media & Ya & Sebagian & Tidak \\
\hline 1 & $\begin{array}{l}\text { Kemampuan menyusun alur } \\
\text { cerita }\end{array}$ & 12 & 10 & 6 \\
\hline 3 & $\begin{array}{l}\text { Kemampuan Menentukan } \\
\text { Setting cerita }\end{array}$ & 23 & 5 & - \\
\hline 4 & $\begin{array}{l}\text { Kemampuan menentukan } \\
\text { karakter tokoh }\end{array}$ & 23 & 5 & - \\
\hline 5 & $\begin{array}{l}\text { Kemampuan membuat } \\
\text { sketsa }\end{array}$ & 20 & 8 & - \\
\hline 6 & $\begin{array}{l}\text { Kemampuan mewarna } \\
\text { gambar }\end{array}$ & 28 & - & - \\
\hline 7 & $\begin{array}{l}\text { Menyusun dialog dalam } \\
\text { gambar }\end{array}$ & 13 & 12 & 3 \\
\hline 8 & $\begin{array}{l}\text { Membuar Cerita dalam } \\
\text { komik }\end{array}$ & 18 & 10 & - \\
\hline 9 & $\begin{array}{l}\text { Mengikuti pembelajaran } \\
\text { dengan sungguh-sungguh }\end{array}$ & 23 & 5 & - \\
\hline 10 & $\begin{array}{l}\text { Kerja Sama dalam } \\
\text { kelompok }\end{array}$ & 17 & 10 & 1 \\
\hline
\end{tabular}

Hasil yang diperoleh dari validasi ahli yang dilakukan oleh $d u a$ orang adalah s bagaimana Tabel 6berikut:

Tabel 6. Data Validasi Ahli

\begin{tabular}{|c|l|c|c|}
\hline \multirow{2}{*}{ No } & \multicolumn{1}{|c|}{ Aspek Yang Dinilai } & \multicolumn{2}{c|}{ Observer } \\
\cline { 3 - 4 } & \multicolumn{1}{|c|}{1} & 2 \\
\hline 1. & $\begin{array}{l}\text { Strategi pembelajaran sesuai } \\
\text { karakteristik materi pembelajaran }\end{array}$ & 4 & 4 \\
\hline 2. & $\begin{array}{l}\text { Strategi pembelajaran menggunakan } \\
\text { media (bahan dan alat) yang mudah } \\
\text { diperoleh }\end{array}$ & 4 & 3 \\
\hline 3. & $\begin{array}{l}\text { Strategi pembelajaran dapat } \\
\text { diterapkan bagi siswa tingkat Sekolah } \\
\text { Menengah Pertama (SMP) }\end{array}$ & 4 & 4 \\
\hline 4. & $\begin{array}{l}\text { Strategi pembelajaran memiliki } \\
\text { kemenarikan bagi peserta didik dalam } \\
\text { pembelajaran }\end{array}$ & 4 & 4 \\
\hline 5. & $\begin{array}{l}\text { Strategi pembelajaran menggugah } \\
\text { keaktifan peserta didik. }\end{array}$ & 4 & 4 \\
\hline 6. & $\begin{array}{l}\text { Strategi pembelajaran dapat } \\
\text { memotivasi peserta didik untuk } \\
\text { belajar (berkreasi) }\end{array}$ & 4 & 3 \\
\hline 7. & $\begin{array}{l}\text { Strategi pembelajaran menunjang } \\
\text { pencapaian tujuan pembelajaran }\end{array}$ & 4 & 4 \\
\hline 8. & $\begin{array}{l}\text { Strategi pembelajaran memiliki nilai } \\
\text { efisien dalam pembelajaran }\end{array}$ & 4 & 4 \\
\hline 9. & $\begin{array}{l}\text { Strategi pembelajaran mengandung } \\
\text { nilai-nilai budaya Probolinggo }\end{array}$ & 4 & 4 \\
\hline 10. & $\begin{array}{l}\text { Strategi pembelajaran dapat } \\
\text { mengembangkan kompetensi kreatif, } \\
\text { dan kolaboratif }\end{array}$ & 4 & 38 \\
\hline & \multicolumn{1}{|c|}{ Jumlah komunikatif, } & 40 & \\
\hline & & 4 \\
\hline
\end{tabular}

Data di atas menunjukkan bahwa observer I memberikan penilaian 40 dari total nilai 40 dan 


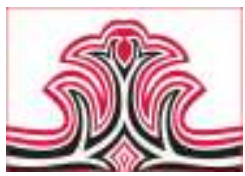

obs erver II memberikan penilaian 38 dari totalnilai 40. Dari data ini dapat di tentukan prosentase penilaian sebagaiberikut:

\section{Observer I}

$$
\text { Persentase }=\frac{40}{40} \times 100 \%
$$$$
=100 \%
$$

\section{Observer II}

$$
\begin{aligned}
\text { Persentase } & =\frac{38}{40} \times 100 \% \\
& =95 \%
\end{aligned}
$$

Jika dirata-rata, dapat diperoleh persentase sebagai berikut: $100+95: 2=97,5$. 97,5 berada pada rentang nilai baik sekali. Sehingga dapat ditarik kesimpulan bahwa Pengembangan Strategi Kreasi Komik Putar bertema Probolinggoan memiliki tingkat efisiensi yang sangat ting gi/ baik.

\section{6).Hasil Evaluasi Program (Strategi Kreasi Komik Putar Bertema Probolinggoan)}

Tabel 6 tentang Hasil Evaluasi Program ( Strategi Kreasi Komik Putar bertema Probolinggoan) di atas dapat di analisis ke dalam Tabel 7 sebagai berikut:

Tabel 7. Analisis Hasil Evaluasi Program (Strategi Kreasi Komik Putar Bertema Probolinggoan)

\begin{tabular}{|l|l|}
\hline \multicolumn{1}{|c|}{ Uraian } & \multicolumn{1}{|c|}{ Pencapaian } \\
\hline $\begin{array}{l}\text { Keaktifan Siswa } \\
\text { dalam Pembelajaran }\end{array}$ & $85 \%$ Siswa aktif tercapai \\
\hline $\begin{array}{l}\text { Pencapaian tujuan } \\
\text { Pembelajaran }\end{array}$ & $\begin{array}{l}\text { Tercapai peningkatan: } \\
-\begin{array}{c}\text { Menyusun alur cerita } 60.71 \%, \\
\text { Teknik menggambar 64, 29\% } \\
\text { Menentukan karakter tokoh } \\
\text { sebesar 25\%. }\end{array}\end{array}$ \\
\hline Materi pembelajaran & Mudah didapatkan \\
\hline $\begin{array}{l}\text { Hasil ikutan sebagai } \\
\text { dampak pembelajaran }\end{array}$ & Tercapai \\
\hline
\end{tabular}

Berdas ar tabel di atas dijelaskan bahwa keaktifan siswa dalam belajar berada pada angka $85 \%$ sis wa aktif. Ini menunjukkan bahwa pelaksanaan pembelajaran disimpulkan berada pada kondisi aktif. Keaktifan ini disebabkan oleh materi yang menarik sehingga menggugah siswa untuk bekerja secara aktif dengan kelompok. Dan dari pencapaian tujuan pembelajaran berupa peningkatan kemampuan menggambar komik mencapai $60.71 \%$ untuk menyusun alur cerita, 64, 29 $\%$ teknik, menggambarmenentukan dan $25 \%$. menbuat karakter tokoh. Sedangkan dari tujuan ikutan juga tercapai. Ini berarti penerapan Strategi Kreasi Komik Putar bertema Probolinggoan sangat layak untuk diterapkan dalampembelajaran seni budaya di sekolah.

\section{Pembahas an}

Pembelajaran Seni Budaya dengan mengangkat kearifan lokal seperti tema probolingoan ini sangat
Gorga : Jurnal Seni Rupa

Volume 09 Nomor 02 Juli-Desember 2019

p-ISSN: 2301-5942 | e-ISSN: 2580-2380

besar guna dan manfaatnya. seperti yang dis ampaikan oleh Rohidi(2014:1) bahwa melalui cara mengenalkan siswa kepada proses artistik dan memasukkan unsur budaya mereka ke dalam pendidikan, akan menumbuhkan pada setiap individu ciri-ciri kreatif, inisiatif, dan imajinasi yang subur, kebijaksanaan emosi, arah moral, kemampuan, bertindak s ecara kritis, otonomi, dan kebebasan berfikir serta bertindak.

Secara rinci strategi kreasi komik putar bertema probolinggoan membelajarkan siswa tentang kreatif, inovasi, pelestarian budaya, pengembangan media , serta berkolaborasi.

\section{1). Kreatif}

Kreatif artinya Kreasi Komik Putar bertema Probolinggoan yang dijadikan aktivitas dalam pembelajaran menggambar komik, memberikan pengalaman kreatif dan inovatif melalui proses berkarya yang tidak biasanya. Pembelajaran menggambar komik melalui Strategi Kreasi Komik Putar bertema Probolinggoan sis wa dilatih berkarya dengan menyimpang dari bentuk-bentuk yang sudah ada. Selama ini siswa mengetahui keberadaan komik berbentuk buku atau strip. Melalui Kreasi Komik Putar bertema Proboling goan akan memberikan pengalaman bagi siswa untuk berfikir dan bertindak kreatif. Pengalaman iniakan merangs ang potensi kreatif siswa untuk berkembang. Melalui kegiatan ini diharapkan akan muncul gagasan-gagasan baru bagi siswa karena terbiasa membuat hal yang baru (inovatif). Kreasi komik putar menjadi sebuah proses pembelajaran yang akan menjadi lingkungan yang berpotensi dan berpengaruh bagi pengembangan kreativitas siswa.

\section{2). Inovatif}

Inovatif artinya bahwa pembelaran men ggambar komik melalui Strategi Kreasi Komik Putar bertema Probolinggoan memberikan pengalaman mencipta/kreasi melalui hasil pemikiran sis wa sendiri. Salah satu karakter dari pembelajaran Seni Budaya adalah pengembangan kreatifitas dan orisinalitas. Kreativitas dan orisinalitas ini merupakan paduan kondisi yang saling mengikat. Kreativitas terbentuk dari karya yang orisinil, sedangkan untuk membuat karya yang orisinil diperlukan kreativitas. Agar terbentuk siswa yang kreatif yang mampu membuat karya yang orisinil, maka pengalaman selama mereka belajar harus dapat memberikan kontribusi untuk tumbuh dan berkembangnya kreatif dan orisinil dalam diri siswa. Kondisi ini akan terwujud bila kondisi pembelajaran yang dilakukan selalu memberikan pengalaman kreatif dan inovatif. 
Kreasi Komik Putar bertema probolinggoan dalam pembelajaran menggambar komik dilaksanakan melalui tahapan belajar dimana siswa mencoba dan berimajinasi membuat bentuk visual suatu cerita berdasar penafsiran mereka sendiri. Proses belajar mereka bukan meniru gambar yang sudah ada kemudian mereka gambar sama persis. Pembuatan karya bukan hasil mencontoh apa adanya dari karya yang sudah dibuat, melainkan wujud yang diperoleh melalui proses pengembangan kemampuan berfikir dan teknik berkarya siswa sendiri. Kebiasaan bertindak kreatif dan inovatif akan menjadikan sis wa memiliki jiwa yang kreatif dan inovatif.

\section{3). Pelestarian Budaya}

Bangsa Indonesia kaya akan budaya, sebagai hasil eksistensi masyarakat indonesia sejak masa primitif hingga modern. Bentuk hasil budaya itu tersebar di berbagai suku di seluruh wilayah Nusantara. Dari yang tangibel (kebendaan) maupun intangibel (bukan kebendaan). Hasil budaya bangsa tersebut memiliki keunikan tersendiri dari masing-masing daeah. Sehingga memperkaya bentuk dan jenisnya.

Keunikan budaya bangsa menarik orang-orang asing untuk mempelajarinya. Sebagai kajian maupun sumber pengetahuan, sehingga banyak penulis asing yang menulis tentang kebudayaan Indonesia. Dari deretan penulis tentang budaya Indonesia justru didominasi oleh orang asing. Kenyataan ini sebenarnya merupakan tantangan bagi generasi muda ketika harus belajar tentang Indonesia kepada orang asing.

Kekayaan budaya bangsa itu merupakan modal kultural bagi warga indonesia khususnya generasi muda. Oleh karenanya perlu dilestarikan pada generasi muda. Menurut Sedyawati (2006:280) upaya pelestarian budaya bangsa yang tersebar itu dapat dilakukan melalui beberapa kegiatan yaitu: 1) pendokumentasian secara cermat dengan menggunakan berbagai media yang sesuai; 2) pembahasan dalamrangka penyadaran, khususnya mengenai nilai-nilai budaya, norma, dan estetika; 3) pengadaan acara penampilan yang memungkinkan orang "mengalami" dan "menghayati" Di era global orang sangat mudah mengenal dan melakukan budaya as ing. Ini merupakan ancaman bagi generasi muda. Kebudayaan asing dengan segala bentuk keunggulan media dan sarana (cyber, elektronik, cetak) sangat gencar menancapkan pengaruhnya hingga ke daerah pedalaman. Kita telah paham bahwa banyak bacaan anak-anak yang berorientasi bukan dari budaya Indonesia. Munculnya komik-komik asing merupakan salah satu contoh. Generasi muda lebih mengenal budaya asing daripada
Gorga : Jurnal Seni Rupa

Volume 09 Nomor 02 Juli-Desember 2019 p-ISSN: 2301-5942 | e-ISSN: 2580-2380

budayanya sendiri. Jika generasi muda sudah tidak mengenal lagi budaya bangsa kita maka segala tindakannya akan terlepas dari jati diri dan budaya Indonesia.

Strategi Kreasi Komik Putar bertema Probolinggoan merupakan salah satu upaya menanamkan nilai-nilai budaya pada peserta didik sebagai generasi muda. Melalui kegiatan kreasi komik yang berbasis pada nilai-nilai lokal diharapkan siswa dapat mengenal lingkungan, sosial dan budaya sebagai ruang tempat sis wa bers osialis asi

Sesederhana apapun pengalaman belajar untuk mengenal sosial budaya masyarakatnya, maka kelak akan menjadi siswa sebagai generasi yang dapat menghargai soaial budayanya untuk dijadikan modal membangaun bangsa Indonesia. Dampak dari beberadaan teknologi yang serba kompleks dan menggelobal tidak akan membuat sis wa kehilangan jati diri dan identitas sebagai masyarakat Indonesia. Sehingga pembelajaran seni menjadi pembelajran yang dapat menghaluskan budi dan menebalkan kebangsaan (Dewantara, 1962: 346).

\section{4). Pengembangan Media}

Membelajarkan siswa bagaimana memanfaatkan benda-benda disekitarnya menjadi sumber belajar sekaligus sebagai media berekpresi. Variasi media diharapkan pembelajaran dapat berjalan semakin baik, tidak menjemukan sehingga efektifitas, efisisensi dan suas ana belajar yang menggembirakan dalam proses pembelajaran terlaksana. Belajar dan berekpresi seni bukan hanya menggunakan media yang mahal, tetapi dapat juga dilakukan men ggunakan media yang murah atau apapun (yang masih relevan), termasuk barang bekas.

Media kotak/kerdus bekas banyak tersedia di lingkungan sis wa. Kondis i ini tidak mempersulit bagi siswa. Sehingga siswa mudah mewujudkan kreasi mereka. Smith dan Ragan (dalam Pribadi 2009: 18-19) menyebutkan bahwa indikator pembelajaran sukses adalah efektif, efisien, dan menarik. Efektif berarti pembelajaran yang dilaksanakan dapat mencapai tujuan/ kompetensi yang diharapkan, efisien berarti pelaksanaan pembelajaran tidak terjadi pemborosan baik waktu maupun dana, dan menarik berarti pembelajaran yang dilaksanakan dapat memotivasi siswa untuk mempelajarinya.

Pengalaman ini melatih siswa untuk kreatif menggunakan dan memanfaatkan benda-benda dis ekitarnya untuk diolah menjadi sebuah karya seni. Variasi pembelajaran berkarya seni menggunakan 
berbagai media akan memberikan kesempatan bagi sis wa untuk melatih berfikir kreatif sehigga memiliki dampak positif berupa peningkatkatan pengalaman estetiknya. Pengembangan kreativitas dapat dilakukan melalui hal-hal/ pengalaman yang sederhana, dan pada akhirnya menuju pada yang kompleks sesuai perkembangan berfikir siswa. Penggunaan media yang bervariasijuga memiliki .

Kolaboratif. Strategi Kreasi Komik Putar bertema Probolinggoan y ang dalampembelajarannyadilakukan berkelompok memberikan pengalaman bagi siswa untuk hidup dan beraktivitas bersama. Dalam kelompok yang terdiri dari sis wa yang berkemampuan bervariasi diharapkan dapat menjadi pengalaman belajar yang menggembirakan, saling mengisi antar anggota kelompok sehingga akan terjadi pembelajaran sis wa antarsiswa.

Pembelajaran menggunakan Strategi Kreasi Komik Putar bertema Proboling goan bukan saja berorientasi pada tujuan pembelajaran (instructional effect) tetapi juga (nurturant effect). Pembelajaran menggambar komik selain bertujuan agar siswa dapat menggambar komik, juga bertujuan mencapai dampak ikutan benpa pengembangan karakter kreatif, inovatif, berfikir kritis, kolaboratif, kerja keras serta peka terhadap lingkungan dan budayanya. Sehingga antara siswa yang memiliki bakat dan yang tidak berbakatakan merasakan dampak dari pembelajaran seni.

Penerapan Strategi ini mampu meningkatkan kompetensi siswa dalam menggambar komik yang meliputi: Peningkatan kemampuan membuat alur cerita, peningkatan teknik menggambar, dan peningkatan membuat karakter, dan peningkatan ratarata nilai.

Peningkatan pertama adalah kemampuan membuat alur cerita. Peningkatan kemampuan membuat alur cerita yaitu $60.71 \%$. Ini terjadi karena dalam Strategi Kreasi Komik Putar bertema Probolinggoan diberikan pengalaman menganalisis cerita/ naskah. Siswa mengalami langsung bagaimana menentukan alur cerita berdasar bacaan yeng telah mereka analisis. Sehingga secara otomatis aktivitas pembelajaran menganalisis cerita akan mempermudah bagaimana menetapkan dan membuat alurcerita.

Peningkatan kedua adalah teknik menggambar yaitu $64,29 \%$. Ini berarti terjadi peningkatan yang sangat tinggi. Faktor motivasi siswa dalam menggambar memiliki pengaruh yang kuat untuk membuat gambar komik secara maksimal. Sehingga siswa dapat bekerja
Gorga : Jurnal Seni Rupa Volume 09 Nomor 02 Juli-Desember 2019 p-ISSN: 2301-5942 | e-ISSN: 2580-2380

keras untuk menyelesaikan gambar dengan baik. Diterapkannya media baru, bentuk baru, dan stratategi baru menjadi faktor meningkatnya motivasi sis wa. Hal ini sejalan dengan konsep Sanjaya (2009: 172) bahwa dalam menyusun strategi pembelajaran hendaknya memperhatikan faktor motivasi. Artinya pembelajaran yang akan dilakukan hendaknya dapat memacu motivasi siswa. Sehingga motivasi tersebut dapat meng antarkan pada terciptanya suasana belajar sesuai yang diharapkan.

Peningkatan ketiga adalah peningkatan dalam membuat karakter. Peningkatan kemampuan siswa dalam membuat karakter tokoh sebesar 25\%, Peningkatan ini tergolong rendah bila dibanding dengan aspek yang lain. Membuat karakter tokoh menjadi hal yang paling sulit bagi siswa. Hal ini karena pada kebiasaan sebelumnya kegiatan menggambar dilakukan dengan mencontoh. Sis wa sudah terbiasa dengan model yang kemudian mereka pindah pada bidang gambar. Merubah kebiasaan bukan hal yang mudah. Tetapi ini merupakan langkah awal bag aimana melatih siswa kreatif mengoptimalkan kemampuan yang mereka miliki.

Merubah hal yang sudah biasa dilakukan memang sangat sulit. Tetapi memang harus segera dimulai. Kesulitan peserta didikdalammembuat karakter karena belum terbiasa membuat secara mandiri. Melainkan selalu melihat contoh. Pengembangan Strategi Kreasi Komik Putar bertema Probolinggo merupakan hal baru. Bentuk-bentuk komik belum ditemukan di perpustakaan maupun ditoko buku. Sehing ga peserta didik harus berusaha sendiri bagaimana menyesuaikan antara bacaan/ cerita dengan bentuk visual gambar. Melalui kegiatan ini peserta didik dilatih membuat dan mengkonstruksi melalui modifikasi maupun berkreasi sendiri. Melalui strategi ini pula mereka berlatih kreatif, inovatif dan berfikir kritis. Hal ini sejalan dengan konsep Sanjaya (2009) dalam merancang pembelajaran yaitu menantang. Artinya pembelajaran diupayakan mampu mengekplor semua kemampuan yang dimiliki oleh sis wa.

Dari ketiga peningkatan di atas secara otomatis meningkatkan rata-rata nilai sebesar $75 \%$. Secara global pelaksanaan Pengembangan Strategi Kreasi Komik Putar bertema Probolinggoan yang sudah dilakukan terjadi peningkatan pada sebagian besar siswa dan hanya sebagian kecil yang mengalami penurunan. Terjadinya penurunan ini karena kondisi belajar yang berbeda. Dari individual menjadi berkelompok. Siswa yang tidak terbiasa kerja kelompok akan berpengruh pada proses belajarnya. 
Tetapi ini adalah pembelajaran agar mereka terbiasa dengan kerja berkelompok.

Pembelajaran menggunakan Strategi Kreasi Komik Putar bertema Probolinggoan bukan saja berorientasi pada tujuan pembelajaran (instructional effect) tetapi juga (nurturant effect). Pembelajaran menggambar komik selain bertujuan agar siswa dapat menggambar komik, juga bertujuan mencapai dampak ikutan benupa pengembangan karakter kreatif, inovatif, berfikir kritis, kolaboratif, kerja keras serta peka terhadap lingkungan dan budayanya. Sehingga antara siswa yang memiliki bakat dan yang tidak berbakatakan merasakan dampak dari pembelajaran seni. Kreasi Komik Putar bertema Probolinggoan mirip dengan belajar sambil bermain. Karena proses kreasinya identik dengan membuat benda mainan. Bentuk/ tampilan Kreasi Komik Putar bertema Probolinggoan menyerupai benda yang dapat dimainkan.

Hal ini berbeda dengan penelitian tentang menggambar komik seperti yang dilakukan oleh Suryanto yang menggunakan metode mencontoh sehingga lebih fokus pada pencapaian hasil belajar (instructional effect) tidak pada hasil ikutan (nuturant effect), sedang yang diterapkan dalam penelitian ini berupa penerapan s trategi kreasi yang berdampak pada pencapaian hasil belajar (instructional effect ) sekaligus hasilikutan (nuturant effect).

Fungsi dari penerapan Strategi Kreasi Komik Putar bertema Probolinggoan ini yaitu: 1) untukmemotivasi agar siswa tertarik (karena medianya baru, bentuk komik baru dan dapat dimainkan layaknya mainan, memiliki tantangan dan terpacu untuk melakukan proses menggambar komik dengan sungguh-sungguh; 2) membelajarkan siswa akan kreativitas dengan memanfaatkan kerdus/ kotak bekas menjadi bentuk baru, dari sampah menjadi sesuatu yang bernilai; 3) memberikan pengalaman berinovasi. Bentuk komik yang dikenal oleh peserta didik selama ini berbentuk gambar dua dimensi atau berbentuk buku, dibuat menjaditiga dimensi.

Undang-undang Sisdiknas telah mengamanahkan bahwa pendidikan ditujukan untuk berkembangnya potensi peserta didik agar menjadi manusia yang beriman dan bertakwa kepada Tuhan Yang Maha Esa, berakhlak mulia, sehat, berilmu, cakap, kreatif, mandiri, dan menjadi warga negara yang demokratis dan bertanggung jawab. Itu artinya bahwa, pendidikan harus dapat mengembangkan aspek lahir dan bathin, sehing gamampu menyiapkan peserta didik secara utuh
Gorga : Jurnal Seni Rupa

Volume 09 Nomor 02 Juli-Desember 2019

p-ISSN: 2301-5942 | e-ISSN: 2580-2380

dalam kehidupannya. Keseimbangan capaian tujuan pendidikan tersebut harus selau menjadi prioritas yang dijabarkan dalam setiap proses pembelajaran yang dijabarkan dalambentuk pengetahuan, s piritual, s osial, dan ketrampilan. Untuk mencapai hal tersebut diperlukan sis tempembelajaran yang baik.

\section{KESIMPULAN DAN SARAN}

\section{Kesimpulan}

Hasil penelitian inidapat disimpulkan bahwa:

proses pelaksanaan Strategi Kreasi Komik Putar bertema Probolinggoan dilakukan melalui tahapantahapan sebagai berikut: 1) mengidentifikasi kearifan lokal masyarakat Probolinggo untuk kemudian dipilih salah satu menjadi tema dalamkreasi komik; 2) analisis cerita atau naskah y ang telah ditentukan sebagai tema untuk menentukan plot atau alur cerita, tokoh cerita dan karakternya serta setting cerita; 3) mendes ain gambar komik berdasar hasil analisis; 4) proses kreasi, yaitu memindah gambar desain pada media gambar berupa kerdus/ kotak kemasan yang telah disiapkan, pewarnaan, hingga menyusun bagian-bagian komik menjadi utuh; 5) proses terakhir adalah komunikasi, yaitu masing-masing kelompok melakukan serangkaian presentasi di depan kelas untuk mengkomunikas ikan hasil karyanya pada siswa lain.

Dari penerapan strategi Kreasi Komik Putar bertema Probolinggoan ini diperoleh peningkatan kemampuan menyus un alur cerita cukup ting gi, teknik menggambar cukup tinggi dan menentukan karakter tokoh sebesar masih rendah. Dan dari rata-rata nilai diperoleh kesimpulan bahwa terjadi peningkatan nilai siswa dengan kategori cukup tinggi.

\section{Saran}

Kepada guru, kearifan lokal yang terdapat pada masyarakat Probolinggo belum terakumulasi secara maksimal, sehing ga masih diperlukan penerapan lebih mendalam tentang proses mengangkat cerita/naskah maupun kualitas teknik berkarya sehingga akan diperoleh bentuk gambar komik yang lebih kompleks dan berkualitas.

\section{DAFTAR RUJUKAN}

Dewantara, Ki Hajar. (1962). Pendidikan. Jogjakarta: Taman Sis wa.

Hariadi, C. (2017). Cara Asik Menggambar Komik. Sidoarjo: Media Cerdas.

Pribadi, Benny A. (2009). Model Desain Sistem Pembelajaran. Jakarta: Dian Rakyat.

Purnomo, Eko dkk. (2016). Buku Guru Seni Budaya. Jakarta:Kemendikbud. 
Ratna, Nyoman Kutha. (2013). Glosrium: 1250 Entri Kajian Sastra, Seni, dan Sosial Budaya. Yogyakarta: Pustaka Pelajar.

Samami, Muklas. (2011). Rekonstruksi Pendidikan. Surabaya: Unesa University Press.

Sani, Ridwan A. (2019). Strategi Belajar Mengajar. Depok: Rajagrafindo Pers ada.

Sanjaya, Wina. (2009). Perencanaan dan Desain Sistem Pembelajaran. Jakarta: Kencana.

Sedyawati, Edi. (2008). Keindonesiaan Dalam Budaya. Buku 2. Jakarta: Wedatama Widya Sastra.

Sus anto, Mikke. (2011). Diksi Rupa. Yogyakarta: Dicti Art Lab\&Djagad Art House.

Soeharjdo, A.J. (2011). Pendidikan Seni. Strategi Penataan dan Pelaksanaan Pembelajaran Seni. Malang: Bayumedia Publishing.

Rakhmah, Diyan Nur. (2019). Mampukah Pendidikan Kita Beradaptasi dengan Revolusi Industri 4.0. https://m.kumparn.com Diunduh21-02-2019.

Rohidi, Tjetjep Rohendi. (2019). Pengembang an Media Pembelajaran Pendidikan Seni Budaya Berbasis Kearifan Lokal (Wayang Sebagai Sumber Gasasan) http://journal.unnes.ac.id diunduh 1703-2019.

Undang-Undang Republik Indonesia No. 20 Tahun 2003 Tentang Sistem Pendidikan Nasional. Jakarta: Depdiknas. 